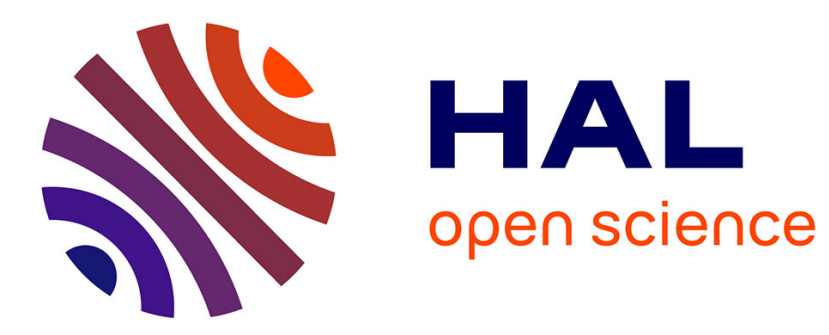

\title{
Belt-parallel mantle flow beneath a halted continental collision: The Western Alps
}

Guilhem Barruol, Mickael Bonnin, Helle Pedersen, Götz H.R. Bokelmann, Christel Tiberi

\section{- To cite this version:}

Guilhem Barruol, Mickael Bonnin, Helle Pedersen, Götz H.R. Bokelmann, Christel Tiberi. Beltparallel mantle flow beneath a halted continental collision: The Western Alps. Earth and Planetary Science Letters, 2011, 302 (3-4), pp.429-438. 10.1016/j.epsl.2010.12.040 hal-00617828

\section{HAL Id: hal-00617828 \\ https://hal.science/hal-00617828}

Submitted on 26 Oct 2016

HAL is a multi-disciplinary open access archive for the deposit and dissemination of scientific research documents, whether they are published or not. The documents may come from teaching and research institutions in France or abroad, or from public or private research centers.
L'archive ouverte pluridisciplinaire HAL, est destinée au dépôt et à la diffusion de documents scientifiques de niveau recherche, publiés ou non, émanant des établissements d'enseignement et de recherche français ou étrangers, des laboratoires publics ou privés. 


\title{
Belt-parallel mantle flow beneath a halted continental collision: The Western Alps
}

\author{
Guilhem Barruol $^{\mathrm{a}, *}$, Mickael Bonnin ${ }^{\mathrm{a}}$, Helle Pedersen ${ }^{\mathrm{b}}$, Götz H.R. Bokelmann ${ }^{\mathrm{a}, 1}$, Christel Tiberi $^{\mathrm{a}}$ \\ a Université Montpellier II, CNRS, Géosciences Montpellier, F-34095 Montpellier cedex 5, France \\ b Laboratoire de Géophysique Interne et Tectonophysique, CNRS, Université Joseph Fourier F38041 Grenoble, France
}

\begin{abstract}
A B S T R A C T
Constraining mantle deformation beneath plate boundaries where plates interact with each other, such as beneath active or halted mountain belts, is a particularly important objective of "mantle tectonics" that may bring a depth extent to the Earth's surface observation. Such mantle deformation can be mapped at scale lengths of several tens of kilometers through the analysis of seismological data and particularly by mapping seismic anisotropy from the splitting analysis of vertically-propagating SKS waves that largely reflect the strain-induced crystal preferred orientations of the rock-forming minerals within the upper mantle. In the present study, we analyse data from approximately 50 broadband seismic stations covering the Western Alps and we provide a coherent picture of upper mantle anisotropy beneath the belt. The large-scale anisotropy pattern is characterized by fast split directions that closely follow the trend of the belt. Moreover, the maximum anisotropy magnitude is not located beneath the internal zones of the belt but instead beneath external units. All suggests that the anisotropy is likely dominated by sublithospheric mantle deformation. We propose that the observed anisotropy pattern can be explained by recent or active mantle flow around the Eurasian slab presently plunging beneath the inner parts of the Alps.
\end{abstract}

\section{Introduction}

During the last decades, the mantle anisotropy pattern, as the surface observable of mantle tectonics (Silver, 1996; Silver et al., 1999), has been defined at an increasing resolution worldwide by seismological data recorded by various permanent networks and temporary deployments and depicted by both surface and body waves (e.g., Debayle et al., 2005; Wüstefeld et al., 2009). The interaction between lithospheric structures and mantle flow is still providing key questions on mantle dynamics, particularly in continental areas where strong deformation is expected to be frozen within the lithosphere while overlying a present-day asthenospheric flow induced by either plate motion or smaller-scale geodynamic processes. In the Western Alps, the number of permanent stations has noticeably increased, and there is now a rather complete and homogeneous instrumental coverage allowing the investigation of mantle dynamic in this halted continental collision.

\footnotetext{
* Corresponding author. Université de La Réunion, CNRS, IPG Paris, Géosciences Réunion, 15 avenue René Cassin, BP 715197715 Saint Denis cedex 9, La Réunion, France. Fax: + 33262262938266 .

E-mail addresses: guilhem.barruol@univ-reunion.fr (G. Barruol), bonnin@gm.univ-montp2.fr (M. Bonnin), Helle.Pedersen@obs.ujf-grenoble.fr (H. Pedersen), Goetz.Bokelmann@univie.ac.at (G.H.R. Bokelmann), tiberi@gm.univ-montp2.fr (C. Tiberi).

${ }^{1}$ Now at: Institute of Meteorology and Geophysics, University of Vienna, Althanstrasse 14, 1090 Vienna, Austria.
}

The present-day shape of the Mediterranean domain is largely controlled by Cenozoic tectonics characterized by a succession of opening of small-size oceanic domains in backarc situations within the closing domain between Africa and Eurasia. The upper mantle structure, depicted from tomographic inversions (Piromallo and Morelli, 2003; Spakman et al., 1993; Wortel and Spakman, 2000), is characterized by the presence of active or remnant slabs beneath the Mediterranean basin. The associated mantle flow that reflects the past and/or present dynamics appears to be controlled by the activity of these numerous small-scale subductions (Faccenna et al., 2001; Faccenna et al., 2004). Recent interpretations of anisotropy in the Mediterranean domain (Jolivet et al., 2009; Lucente et al., 2006; Schmid et al., 2004) suggest that toroidal flows (i.e., flows characterized by vertical vorticity, opposite to the poloidal flow characterized by downdip mantle motion) are likely dominant features during the interaction between slabs and the surrounding mantle (Funiciello et al., 2006; Piromallo et al., 2006; Schellart, 2008). Such flows have been described to occur around the retreating slabs such as beneath the Calabrian arc (Baccheschi et al., 2007), the Apennines (Margheriti et al., 1996; Plomerova et al., 2006; Salimbeni et al., 2008), the Gibraltar arc (Buontempo et al., 2008; Diaz et al., 2010), the Hellenic arc (Hatzfeld et al., 2001), and probably the Carpathian arc (Ivan et al., 2008). In the vicinity of these subductions, mantle flow is described as being dominated by trench-normal directions on the backarc side and by trench-parallel directions on the "ocean" side, i.e., primarily beneath the subducting slab (Margheriti et al., 2003). 
In this study, we investigate the upper mantle anisotropy beneath the Western Alps by measuring the splitting of teleseismic SKS core phases. These shear waves record large-scale anisotropy produced by lattice-preferred orientations (LPO) of rock-forming minerals and particularly of olivine that represents the major upper mantle volume, which develop in response to tectonic strain (Mainprice et al., 2000; Nicolas and Christensen, 1987; Savage, 1999; Silver and Chan, 1991). We present here our results obtained on more than 50 seismic stations in the Western Alps region (their location and network are listed in Supplementary Table S1) and discuss them in the geodynamic frame of the Eurasia-Africa convergence, in terms of sublithospheric and asthenospheric flow interacting with the subducting plate.

\section{Method and data}

A frequently-used technique for investigating upper mantle anisotropy below seismic stations is to measure the splitting of teleseismic shear waves such as SKS core phases (see examples in Supplementary Fig. S1). The measured splitting parameters are the delay time ( $\delta \mathrm{t})$ between the two split waves, related to the strength of anisotropy and to the path length within the anisotropic medium, as well as the azimuth of the fast split wave polarization $(\phi)$, related to the orientation of the pervasive fabric (foliation and lineation) crossed by the wave. Despite a poor vertical resolution, vertically-propagating SKS waves are wellsuited for investigating upper mantle strain with a lateral resolution of few tens of kilometers since their Fresnel zones have radii of 40 to $60 \mathrm{~km}$ at depth of 100 and $200 \mathrm{~km}$ respectively (e.g., Alsina and Snieder, 1995; Margheriti et al., 2003). To make a systematic mapping of upper mantle anisotropy from SKS splitting in the Western Alps, we used data from various permanent and temporary networks (Fig. 1 and Table 1): 1) the Swiss permanent digital network SDSN (http://www.seismo.ethz.ch/) that provided data from 23 broadband stations for the period 20062008 (red diamonds) which are available at Orfeus data center (http:// www.orfeus-eu.org/), 2) the Italian RSNI (Regional Seismic network of Northern Italy) that provided data for 5 broadband stations (green squares) for the period 2006 to 2008 (http://www.dipteris.unige.it/ geofisica/), 3) the French RLBP (Réseau Large Bande Permanent) that provided data for 10 broadband stations (black circles) for the period 2000-2009 (http://websismo.unice.fr/), 4) the temporary deployment of 11 broadband stations ("Alpes" experiment, PI H. Pedersen) indicated by red triangles, that were recording during the period 2004-2007 (http://bdsis.obs.ujf-grenoble.fr/). We also integrate in this work previous SKS splitting measurements performed on data from the RosAlp network (Barruol et al., 2004) marked by blue diamonds, from the temporary TRACK experiment in the French Massif Central (Barruol and Granet, 2002) indicated by white triangles, and from the Geoscope station SSB (Barruol and Hoffmann, 1999) indicated by a green circle.

Distinct, high signal-to-noise ratio SKS phases, were extracted and analysed for events with magnitude $\left(\mathrm{M}_{\mathrm{w}}\right)$ larger than 6.0 occurring at epicentral distance in the range $85^{\circ}$ to $120^{\circ}$. The splitting parameters, i.e., the azimuth of the fast axis polarization $\phi$ and the delay time $\delta t$ between the fast and slow components of the two split shear waves were obtained by using the SplitLab software (Wüstefeld et al., 2008) and the minimum eigenvalue method (Silver and Chan, 1991). These individual $\phi$ and $\delta$ t results are listed in Supplementary Table S2. A set of splitting examples is shown in Supplementary Fig. S1 to illustrate the quality of the measurements but also the continuous rotation of the fast split shear waves around the Alpine belt. In most cases, seismograms have been band-pass filtered, typically between 0.02 and $0.2 \mathrm{~Hz}$, to remove high frequency and long period signals. The influence of the frequency content of the SKS phases has been systematically investigated by testing a set of 10 different bandpass filters of various widths without evidencing any frequency-dependent behaviour of the splitting parameters.
Systematic investigation of SKS splitting at the stations from the various seismic networks in the Western Alps provided approximately 2000 individual SKS splitting measurements, from which 1200 display evidence of clear splitting. Among those, 644 were of good quality, 429 of fair quality and 125 of poor quality (all these non-null measurements are listed in Supplementary Table S2). 800 events provided "null" splitting measurements, i.e., were devoid of any energy of the SKS phase on the transverse component and therefore of any detectable splitting, 355 of which were of high quality.

The quality of each individual measurement is determined by two independent methods: i) An automatic quality factor (QF) calculated within SplitLab (Wüstefeld et al., 2008) that characterizes the differences between results obtained from the rotation-correlation and eigenvalue splitting techniques (Wuestefeld et al., 2010) and that varies between -1.0 (perfect null) to +1.0 (perfect splitting). ii) A "manual" quality factor for each measurement (good, fair, or poor), as defined in a previous publication (Barruol et al., 1997) and depending on the user evaluation of the signal-to-noise ratio of the initial waveform, of the correlation between the fast and slow shear waves, of the linearization of the polarization on the transverse component, and of the linear pattern of the particle motion in the horizontal plane after correction and the size of the $95 \%$ confidence area. In the present study, the two techniques show very good agreements: manuallyqualified good measurements have generally high QF. For instance, among our 644 good measurements, 80\% have automatic QF larger than 0.5 and only $8 \%$ have negative QF. We observed in a few cases apparent contradiction between automatic and manual quality. For example, PCP station is characterized by a large number of good measurements with negative QF. As explained below, PCP likely resides above a complex structure that may generate some waveform complexity and that may be the source of this apparent contradiction.

\section{Anisotropy pattern beneath the Western Alps}

The observed fast azimuths $\phi$ show clear spatial coherence, and a pattern approximately parallel to the curvature of the Alpine belt. The directions of these 644 good-quality measurements plotted as a function of latitude (Fig. 2) show indeed $\phi$ trending from EW to $\mathrm{N} 120^{\circ} \mathrm{E}$ in the south and $\phi$ trending $\mathrm{N} 030^{\circ} \mathrm{E}$ to $\mathrm{N} 070^{\circ} \mathrm{E}$ in the north, with a smooth and continuous variation between the two areas, despite a small gap in the instrumental coverage between latitudes 45.2 and $45.8^{\circ} \mathrm{N}$. Looking in more details at the individual splitting measurements obtained at each station and presented as stereographic projections or projected on a map at 0 and $150 \mathrm{~km}$ depth (Fig. 3 and Supplementary Figs. S2, S3, S4 and S5) allows visualizing the SKS waves sampling region, that depends on the seismic event backazimuth. The south-eastern France anisotropy pattern including the Corsica station SMPL is characterized by $\phi$ trending close to EW at the Italian border, as described in an earlier study (Barruol et al., 2004), and by a gradual clockwise rotation toward NW-SE directions for stations in the external domains of the belt and toward the French Massif Central. Some SE France stations (STET is the best example) display evidence of backazimuthal variations of the splitting parameters (Barruol et al., 2004) with NE incoming events providing smaller $\delta$ t and $\phi$ closer to EW compared to the SW incoming events that provide larger $\delta$ t and $\phi$ trending SE-NW. These variations are clearly visible on the stereographic projections on the supplementary Fig. S2 and may suggest dipping structures or several layers of anisotropy, but are also consistent with lateral heterogeneities. The presence of a slab in the upper mantle beneath the Po plain, as evidenced by tomographic studies (Lippitsch et al., 2003; Piromallo and Faccenna, 2004) may represent such large-scale heterogeneity.

The 2004-2007 temporary deployment of seismological stations along an EW transect from the internal Alps to the Massif Central (red triangle on Figs. 1 and 3) filled a gap between SE France and the Swiss networks. It provides additional evidence for this NW-SE trend (at 


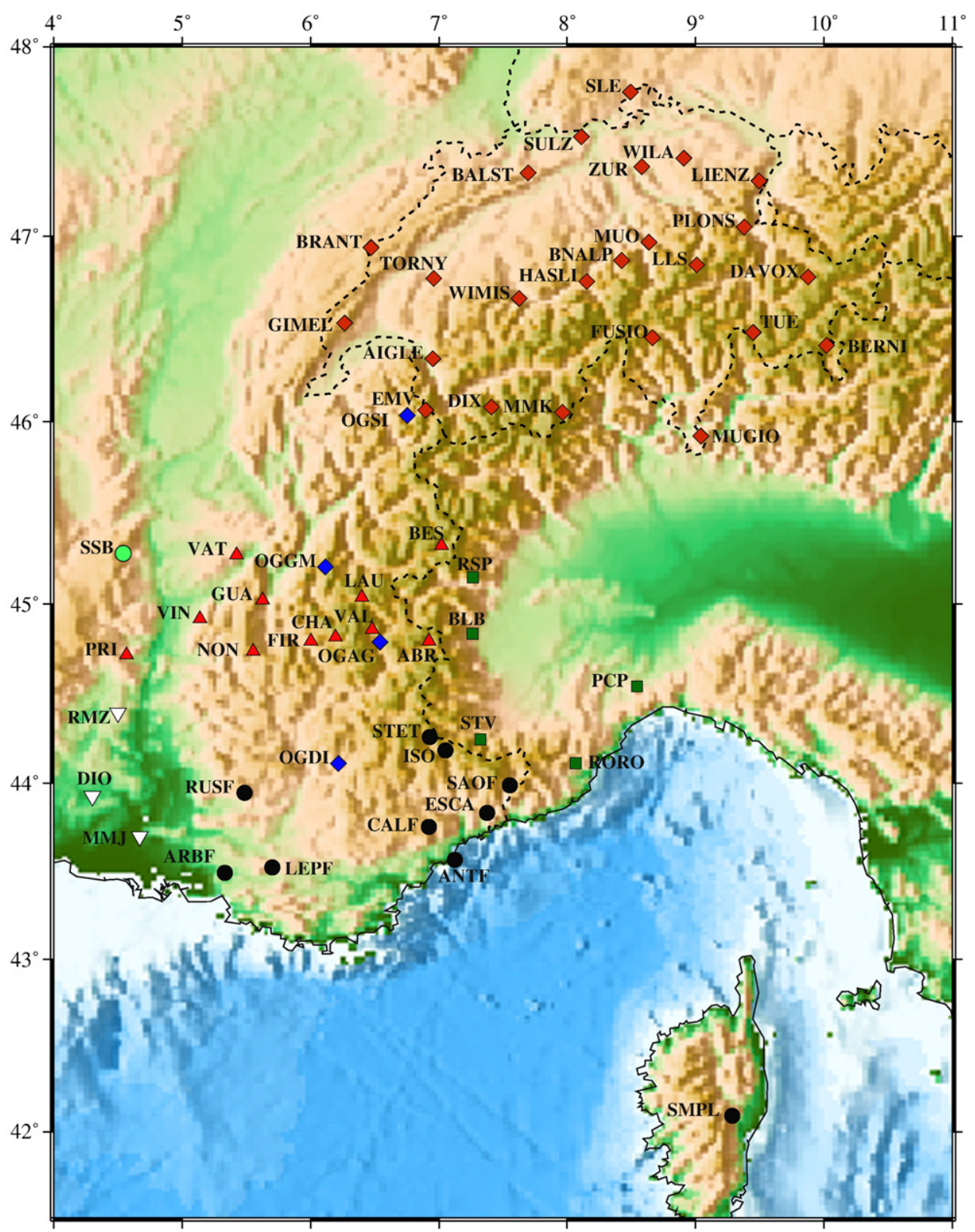

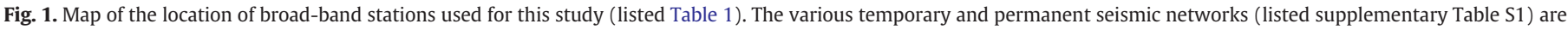

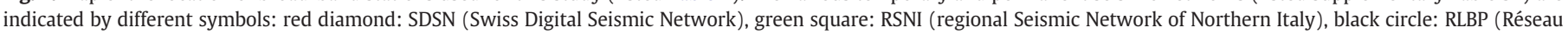
Large Bande Permanent), red triangle: Alps experiment, blue diamond: RosAlp network, green circle,: Geoscope, white triangle: TRACK stations (Barruol and Granet, 2002).

station VAT for instance with $\phi=-41^{\circ} \mathrm{E}$ ), and confirms a northward gradual clockwise rotation of $\phi$ from EW in the South to NS in the French northern Alps, previously documented by two stations from the RosAlp network (Barruol et al., 2004) (OGGM and OGSI).

Further north, stations from the Swiss seismological network complete this gradual clockwise $\phi$ rotation (Fig. 3 and Supplementary Fig. S3 and S4). The pattern is characterized by smooth and continuous variations in fast directions from NS-trending $\phi$ in the Western Switzerland, compatible with the pattern previously observed in France at $\mathrm{OGGM}$ and $\mathrm{OGSI}$, to $\mathrm{N} 060^{\circ} \mathrm{E}$ trending $\phi$ in the easternmost part of Switzerland, consistent with the observations further east along the TRANSALP profile on a transect between Austria and the Adriatic sea (Kummerow and Kind, 2006). This pattern appears consistently for individual events from the entire network (Fig. 3), and similarly in the mean anisotropic parameters presented in Fig. 4 calculated from the good quality measurements. Swiss stations do not show clear evidence of backazimuthal variation of these parameters in the SKS period ranges (i.e., between 5 and 20 s), yet the azimuthal coverage is uneven. The seismic rays are mostly incident within the NE and SW quadrant.

The fast azimuth's $\phi$ pattern we observe from SKS wave splitting is therefore dominated by an orogen-parallel preferred orientation. This might appear as in contradiction with the study from Fry et al. (2010) who used short period Rayleigh waves generated by ambient noise and who evidenced a layered azimuthal anisotropy beneath the Alps characterized by a belt-parallel fast direction at short period and a belt-perpendicular anisotropy at longer period attributed respectively to lower crustal and uppermost mantle anisotropy. These two studies can be reconciled by considering the difference in the depth extent: ambient noise tomography provides well resolved information down to $28 \mathrm{~s}$ period Rayleigh waves (i.e., mostly sensitive in the $20-70 \mathrm{~km}$ depth range), whereas SKS waves with a typical period of $10 \mathrm{~s}$ are sensitive to pervasive structures of much larger scale $(80 \mathrm{~km})$ and integrate the deformation-induced anisotropy along the vertical ray 
Table 1

Station locations (sorted alphabetically) and mean shear wave splitting parameters calculated at each station using the good quality measurements. The number of events used is also indicated.

\begin{tabular}{|c|c|c|c|c|c|c|c|}
\hline Station & $\begin{array}{l}\text { Lat. } \\
\left({ }^{\circ} \mathrm{N}\right)\end{array}$ & $\begin{array}{l}\text { Lon. } \\
\left({ }^{\circ} \mathrm{E}\right)\end{array}$ & $\begin{array}{l}\phi \\
\left({ }^{\circ}\right)\end{array}$ & $\begin{array}{l}\text { Error_ } \phi \\
\left({ }^{\circ}\right)\end{array}$ & $\begin{array}{l}\delta \mathrm{t} \\
(\mathrm{s})\end{array}$ & $\begin{array}{l}\text { Error_st } \\
\text { (s) }\end{array}$ & $\begin{array}{l}\text { Number of } \\
\text { measurements }\end{array}$ \\
\hline ABR & 44.795 & 6.924 & -53.40 & 17.29 & 1.80 & 0.46 & 6 \\
\hline AIGLE & 46.342 & 6.953 & 11.47 & 9.57 & 1.86 & 0.22 & 14 \\
\hline ANTF & 43.564 & 7.123 & 90.72 & 7.89 & 1.12 & 0.23 & 16 \\
\hline ARBF & 43.492 & 5.332 & 100.58 & 6.65 & 1.09 & 0.11 & 29 \\
\hline BALST & 47.336 & 7.695 & 37.82 & 15.45 & 1.66 & 0.47 & 5 \\
\hline BERNI & 46.413 & 10.022 & 54.61 & 10.11 & 1.12 & 0.04 & 2 \\
\hline BLB & 44.835 & 7.263 & -20.84 & 26.70 & 0.90 & 0.31 & 7 \\
\hline BRANT & 46.938 & 6.473 & 33.24 & 21.98 & 0.96 & 0.65 & 4 \\
\hline CALF & 43.753 & 6.922 & 107.18 & 3.44 & 1.24 & 0.10 & 62 \\
\hline DAVOX & 46.781 & 9.880 & 60.90 & 9.75 & 1.04 & 0.25 & 9 \\
\hline DIX & 46.080 & 7.408 & 20.85 & 5.69 & 1.38 & 0.22 & 14 \\
\hline EMV & 46.063 & 6.899 & 1.17 & 10.74 & 1.50 & 0.24 & 17 \\
\hline ESCA & 43.831 & 7.374 & 100.28 & 4.56 & 1.25 & 0.21 & 19 \\
\hline FIR & 44.794 & 6.002 & -54.60 & 7.84 & 1.54 & 0.12 & 10 \\
\hline FUSIO & 46.455 & 8.663 & 44.65 & 7.59 & 1.00 & 0.20 & 13 \\
\hline GIMEL & 46.535 & 6.266 & 7.25 & 9.58 & 1.22 & 0.22 & 11 \\
\hline GUA & 45.023 & 5.626 & -38.07 & 35.50 & 1.36 & 0.78 & 5 \\
\hline HASLI & 46.757 & 8.151 & 35.37 & 9.69 & 1.58 & 0.26 & 15 \\
\hline ISO & 44.184 & 7.050 & -57.76 & 33.00 & 1.47 & 1.14 & 3 \\
\hline LAU & 45.036 & 6.401 & -52.15 & 17.10 & 1.61 & 0.33 & 3 \\
\hline LEPF & 43.523 & 5.702 & -67.81 & 11.73 & 1.08 & 0.39 & 7 \\
\hline LIENZ & 47.295 & 9.493 & 52.94 & 10.18 & 1.44 & 0.19 & 17 \\
\hline LLS & 46.847 & 9.008 & 43.95 & 4.11 & 1.34 & 0.13 & 15 \\
\hline MMK & 46.051 & 7.964 & 28.85 & 18.47 & 1.23 & 0.38 & 9 \\
\hline MUGIO & 45.922 & 9.042 & 55.36 & 10.01 & 0.96 & 0.52 & 7 \\
\hline MUO & 46.968 & 8.637 & 44.45 & 7.63 & 1.34 & 0.19 & 12 \\
\hline NON & 44.738 & 5.554 & -42.28 & 31.80 & 1.45 & 1.37 & 3 \\
\hline OGAG & 44.786 & 6.538 & -43.01 & 5.19 & 1.49 & 0.54 & 6 \\
\hline OGDI & 44.108 & 6.225 & 100.42 & 9.47 & 1.32 & 0.23 & 17 \\
\hline PCP & 44.541 & 8.545 & 86.76 & 12.00 & 1.14 & 0.25 & 19 \\
\hline PLONS & 47.049 & 9.381 & 59.93 & 5.88 & 1.42 & 0.13 & 18 \\
\hline PRI & 44.716 & 4.567 & -26.83 & 19.21 & 1.20 & 0.55 & 1 \\
\hline RORO & 44.112 & 8.066 & 42.88 & 24.37 & 1.04 & 0.49 & 2 \\
\hline RSP & 45.148 & 7.265 & -31.87 & 22.78 & 0.69 & 0.23 & 7 \\
\hline RUSF & 43.941 & 5.484 & 109.65 & 5.26 & 1.22 & 0.17 & 20 \\
\hline SAOF & 43.986 & 7.553 & 105.87 & 4.60 & 1.26 & 0.12 & 32 \\
\hline SLE & 47.764 & 8.492 & 57.33 & 6.82 & 1.58 & 0.31 & 7 \\
\hline SMPL & 42.094 & 9.285 & 101.03 & 3.98 & 1.44 & 0.09 & 36 \\
\hline STET & 44.259 & 6.929 & 120.95 & 4.97 & 1.53 & 0.16 & 50 \\
\hline STV & 44.245 & 7.326 & -62.98 & 9.35 & 1.60 & 0.35 & 5 \\
\hline SULZ & 47.527 & 8.112 & 45.80 & 11.72 & 1.88 & 0.29 & 5 \\
\hline TORNY & 46.774 & 6.959 & 21.65 & 13.35 & 1.39 & 0.56 & 4 \\
\hline VAL & 44.858 & 6.479 & -37.65 & 6.07 & 1.60 & 0.52 & 1 \\
\hline VAT & 45.271 & 5.423 & -41.10 & 12.19 & 1.39 & 0.46 & 7 \\
\hline VDL & 46.483 & 9.450 & 53.23 & 10.68 & 1.21 & 0.40 & 9 \\
\hline VIN & 44.919 & 5.139 & -36.87 & 18.20 & 1.64 & 0.38 & 1 \\
\hline WILA & 47.415 & 8.908 & 60.19 & 8.88 & 1.68 & 0.15 & 8 \\
\hline WIMIS & 46.665 & 7.624 & 24.09 & 7.89 & 1.39 & 0.16 & 18 \\
\hline ZUR & 47.369 & 8.589 & 52.39 & 14.21 & 1.57 & 0.51 & 5 \\
\hline
\end{tabular}

path, i.e., across lithospheric and sublithospheric widespread structures.

Delay times $\delta$ t from the 644 good quality splitting observations are characterized by a mean value close to $1.4 \mathrm{~s}$ and a standard deviation of $0.4 \mathrm{~s}$ (Fig. 2). 33\% of the measurements are characterized by $\delta t$ larger than $1.5 \mathrm{~s}$, suggesting rather strong anisotropy magnitude or long anisotropic paths beneath the stations. The results we obtain do not show particularly large $\delta$ t at stations in the internal domains of the Alps, where one could have expected a concentration of Alpine deformation, as for instance at MUGIO $(\delta \mathrm{t}=0.96 \mathrm{~s})$ or at RSP $(\delta \mathrm{t}=0.69 \mathrm{~s})$, both from 7 good measurements (Table 1$)$. Instead, we observe rather high $\delta$ t at stations that are clearly in the external domains of the belt, as for instance in the Provence area, at RUSF ( $\delta \mathrm{t}=1.22 \mathrm{~s}$ from 20 good measurements $)$, at AIGLE in the Jura massif $(\delta \mathrm{t}=1.86 \mathrm{~s}$ from 14 good events), and at WILA in the Swiss molasse basin ( $\delta \mathrm{t}=1.68 \mathrm{~s}$ from 8 good splitting). Such behaviour is well visible when the delay times are plotted as a function of distance to the internal zone of the Alps. Fig. 5 shows the mean $\delta$ t values as a function of distance between the stations and the boundary between the Apulian and Eurasian plate (schematized by the red line on the insert map). This diagram clearly shows that we do not observe $\delta$ t that gradually decrease from large values at the internal stations toward the external domains of the belt. Instead, we observe relatively small $\delta$ t ranging between 0.8 and $1.2 \mathrm{~s}$ at stations close to that boundary in the internal domain of the belt, and increasing $\delta t$ (larger than $1.4 \mathrm{~s}$ ) for stations located at larger distances from this boundary (between 50 and $200 \mathrm{~km}$ ), as shown by the mean delay time line calculated along a $50 \mathrm{~km}$ moving window (Fig. 5). Interestingly, the delay times appear to decrease again at distance larger than $200 \mathrm{~km}$, which is also confirmed by the small $\delta$ t observed further west in the Massif Central area (Barruol and Granet, 2002). Although only a small number of stations are installed in the internal domain of the belt and on its Apulian side, which may bias the overall pattern, the robust finding is that SKS splitting at stations in the external domains of the Alps require large anisotropy magnitudes or long anisotropic paths beneath areas where only the upper crust is affected by moderate Alpine deformation such as nappes and folded sedimentary covers. As discussed below and taking into account petrophysical constraints, such large delay times are hardly compatible with a lithospheric anisotropy but suggest a dominant sublithospheric deformation. The point located at approximately $100 \mathrm{~km}$ east from the plate boundary presented in Fig. 5 corresponds to station PCP. As discussed below, this station cannot be considered as being installed in the internal zone of the Alps but is located in the transition region between the Alpine and Apennine belts, above an upper mantle that has likely suffered large transpressional deformation during the Tyrrhenian slab rollback.

As explained above, approximately 800 events do not show any evidence of splitting, and are characterized by a lack of energy on the transverse component of the SKS phase. This may be due to: i) a real absence of anisotropy along the ray path, ii) an initial polarization of the SKS wave parallel to the fast or slow direction in the anisotropic layer, iii) a structure with two anisotropic layers with perpendicular fast anisotropy axes and similar intrinsic delay times or iv) mantle heterogeneities of wavelengths shorter than the SKS wave. The backazimuths of the good quality nulls are plotted at each station on supplementary Fig. S6. Their general trend parallel or perpendicular to the non null splitting directions strongly suggest that these SKS waves were initially polarized at the core-mantle boundary parallel to the fast or slow direction in the anisotropic layer.

\section{Discussion}

\subsection{Anisotropy and deep structure of the Western Alps}

The shape of the Moho discontinuity described in a recent compilation (Tesauro et al., 2008) integrating seismic reflexion and refraction profiles across the Alps (Thouvenot et al., 2007; Waldhauser et al., 1998) shows an eastward and southward dipping European Moho beneath the French and the Swiss Alps respectively, with depths of 40 to $45 \mathrm{~km}$ whereas the westernmost part of the Apulian plate is characterized by a much shallower crust-mantle boundary $(20 \mathrm{~km})$. The associated Bouguer gravity anomaly (Fig. 4a), closely related to the crustal thickness variations, shows on one hand a largescale and arc-shaped negative anomaly beneath the internal and external parts of the belt, where the Moho is deeper than normal, and on the other hand a strong positive anomaly beneath the western part of the Apulian plate where the crust is thinner than normal and beneath the Ivrea body where high density rocks are close to the surface (Masson et al., 1999). At the scale of the Western Alps, and as shown in Fig. 4a, the SKS fast directions we observe closely fit the contours of the Bouguer gravity anomaly and thus the Moho depth (Stehly et al., 2009; Tesauro et al., 2008). This pattern suggests some 

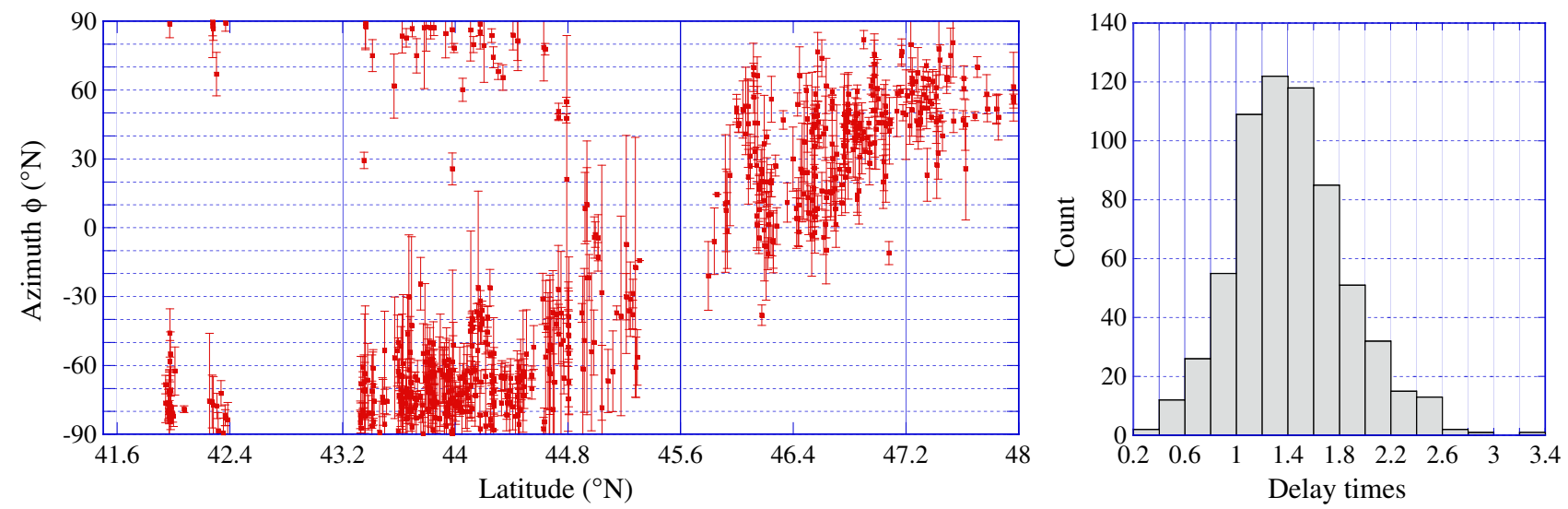

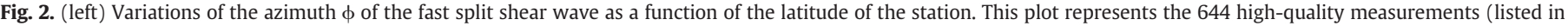

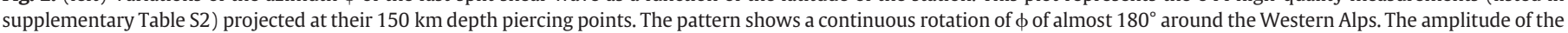
delay times (right) of the good quality measurements roughly shows a maximum distribution centred around $1.4 \mathrm{~s}$.

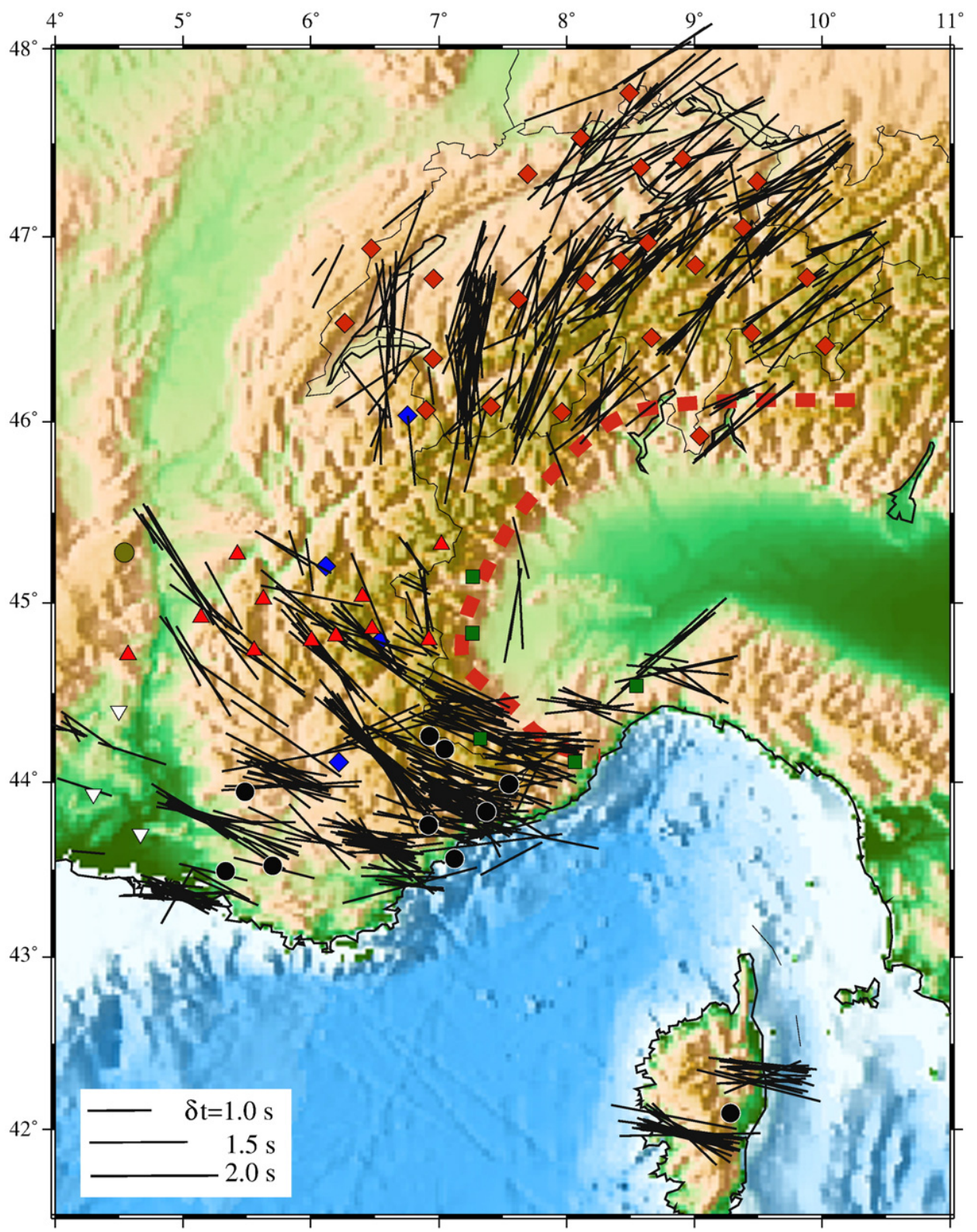

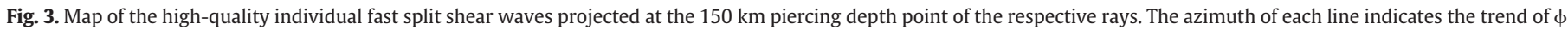
and the length of each segment is proportional to the amplitude of the measured $\delta$ t. The dashed red line indicates the rough location of the Apulian plate boundary. 

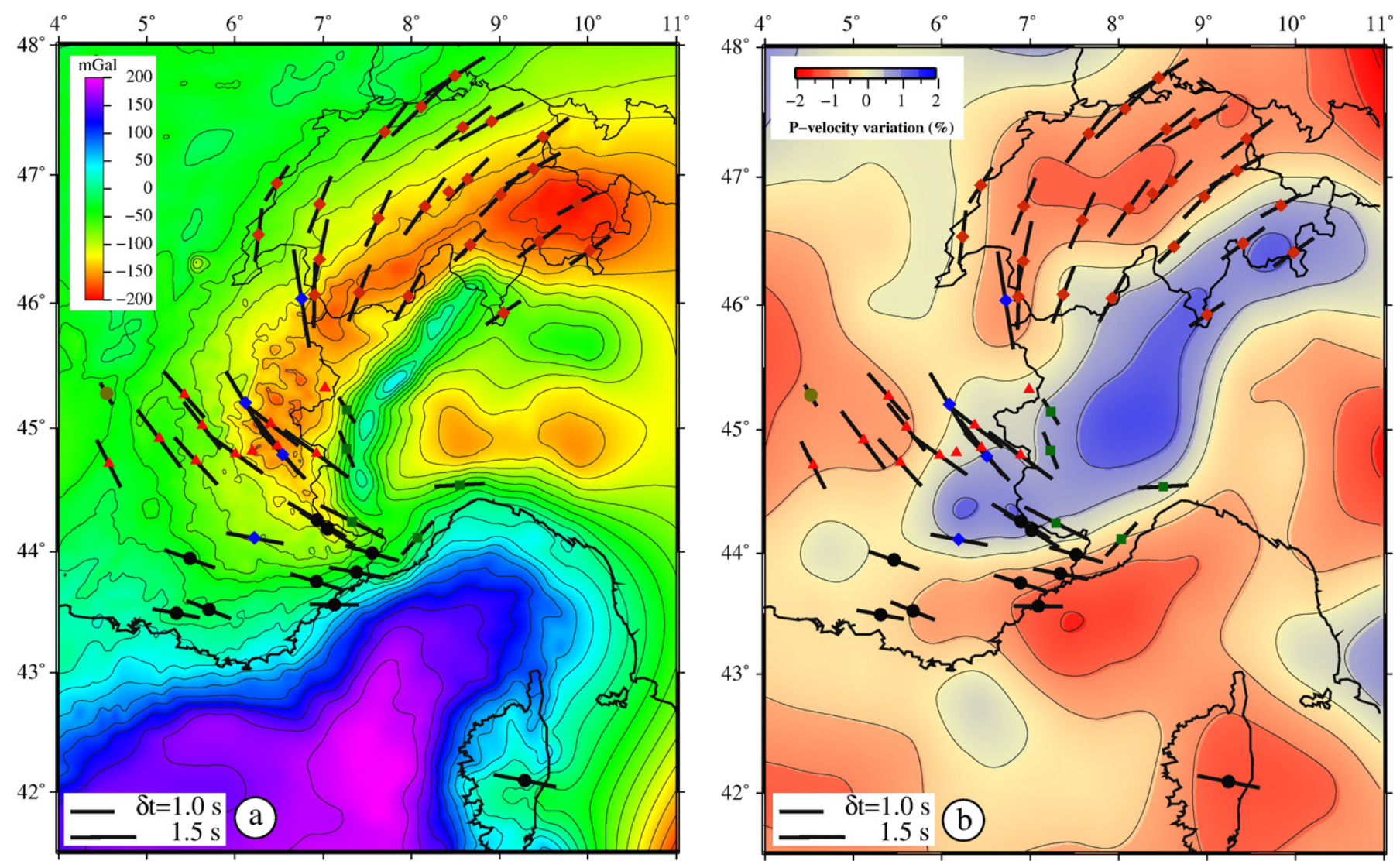

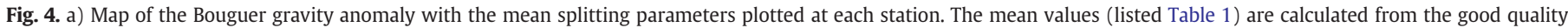

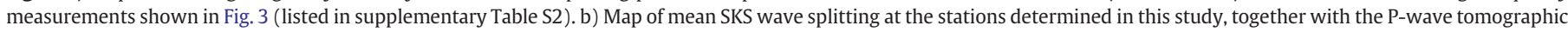
model. Integrating slices between 100 and $200 \mathrm{~km}$ depth (Piromallo and Morelli, 2003), the model shows the fast velocity body beneath the Po plain.

relationship between the physical effects that control mantle deformation and crustal thickness.

Deeper lithospheric structures of the Western Alps are characterized by the presence of a fast seismic velocity body in the upper mantle (see Fig. 4b) that also closely parallels the curvature of the Alpine topography (Lippitsch et al., 2003; Piromallo and Faccenna, 2004; Piromallo and Morelli, 2003). This high-velocity anomaly is clear at 100 and $200 \mathrm{~km}$ and vanishes at a depth of $300 \mathrm{~km}$. It is interpreted as the Eurasian lithospheric slab dipping in the mantle beneath the belt (Lippitsch et al., 2003). Considering that the Alpine subduction may have absorbed at least $500 \mathrm{~km}$ of convergence, the high velocity body lying in the transition zone beneath the Alps (Piromallo and Faccenna, 2004) has also been proposed to represent the remaining part of the cold lithosphere that may have detached about 35 Ma ago from the Alpine slab.

This upper mantle high-velocity body still partly connected to the Eurasian plate is located beneath the outermost part of the Apulian plate, i.e., beneath the western and northern part of the Po plain and fits the curvature of the belt beneath SE France and southern Switzerland. The vertical tomographic sections across the Western
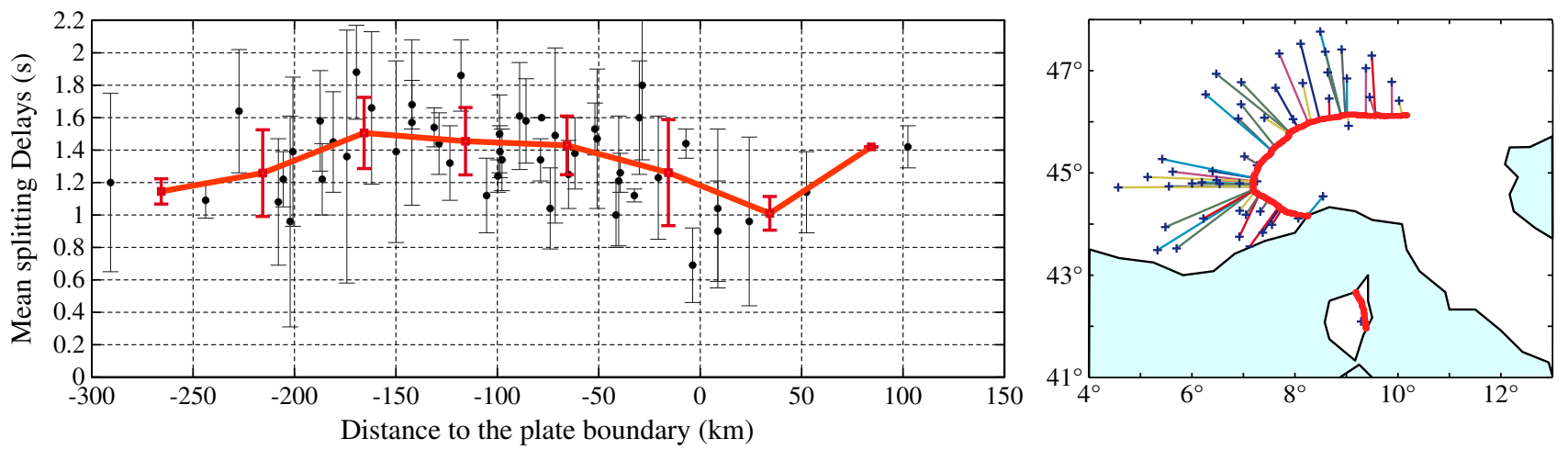

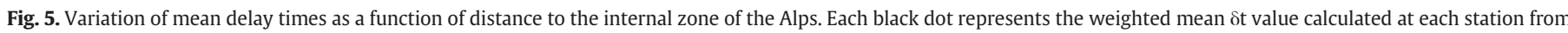

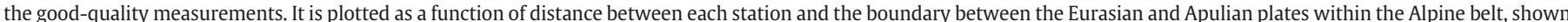

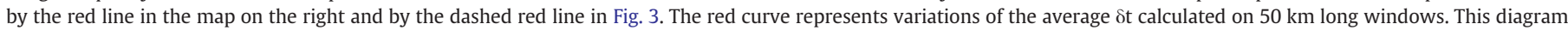

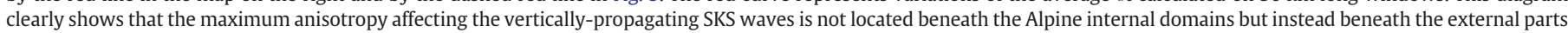
of the belt, suggesting that the anisotropy is likely to lie beneath the lithosphere. 
Alps (Lippitsch et al., 2003; Piromallo and Faccenna, 2004; Piromallo and Morelli, 2003) show that the "Eurasian" high velocity anomaly is steeply dipping beneath the Po plain, implying that most of the seismic stations used in the present study are located in a fore-arc situation, above the gently eastward dipping Eurasian lithosphere. In summary, the mantle flow pattern beneath the Western Alps shows a good correlation with the overall trend of the belt and its crustal structures but also appears to wrap the high velocity anomaly in the upper mantle, inducing therefore ambiguities with respect to the origin of the anisotropy.

\subsection{Lithospheric vs. asthenospheric deformation beneath the Alps}

The large-scale correlation of $\phi i$ ) with the belt curvature (Fig. 2), ii) with the belt topographic heights (Fig. 1), iii) with the Moho depth (Tesauro et al., 2008) and iv) with the Bouguer gravimetric anomaly (Fig. 4a) may at first suggest a close relationship between anisotropy and lithospheric structures.

The first possible origin of lithospheric anisotropy may correspond to ancient, pre-Alpine structures. It can reasonably be ruled out by two arguments though: i) although Hercynian structures, such as pervasive foliations and lineations or shear zones, are poorly defined in the Alps (Matte, 1986), they mainly appear at high angle to the observed anisotropic trend: for instance vertical foliations and shear zones are oriented NS in the Maures Massif in SE France (Vauchez and Bufalo, 1988) where the observed $\phi$ are close to $\mathrm{N} 100^{\circ} \mathrm{E}$ and they do not follow the Alpine curvature. ii) Anisotropy observed at the Corsica station SMPL is trending $\mathrm{N} 100^{\circ} \mathrm{E}$ on average, i.e., parallel to the observations performed in the Provence area, although it is well established that the Corsica-Sardinia bloc suffered a $45^{\circ}$ counterclockwise rotation relative to stable Eurasia since Miocene (Ferrandini et al., 2003; Gattacceca et al., 2007; Maffione et al., 2008). If the anisotropy was lithospheric and inherited from Hercynian orogeny, $\phi$ should be trending $\mathrm{N} 145^{\circ} \mathrm{E}$ in the original Corsica-Sardinia position and therefore at large angle from the very homogeneous SE France regional trend.

The second possible origin for a lithospheric anisotropy could reside in a dominating Alpine deformation. This hypothesis is also unlikely since we observe large $\delta \mathrm{t}(>1.5 \mathrm{~s})$ at the numerous stations located in the external parts of the belt where a pervasive Alpine deformation within the underlying lithosphere is not expected. However, a lithospheric anisotropy cannot be completely ruled out and is likely present to some degree in the internal zones of the belt, at least in the lower crust and uppermost mantle, as suggested by ambient noise and Rayleigh wave azimuthal anisotropy analyses (Fry et al., 2010). It is however important to note that our present SKS splitting study is facing an important geometric bias inducing observational limitations since most of our Western Alps observations are originating from the forearc side of the subduction: assuming an eastward dipping subduction beneath the Western Alps, the deep deformation induced by the Alpine subduction and collision processes is expected to lie beneath the Western and Northern part of the Po plain, where only few seismic stations are installed. This geometric bias is presented on the schematic cross section Fig. 6 and shows that the collision-induced deformation may be therefore hard to detect and to quantify in the present-day recording system geometry.

The overall anisotropy pattern characterized by an almost continuous $180^{\circ}$ rotation of $\phi$ closely related to the high velocity body in the upper mantle (Fig. 4b) may reflect a sublithospheric mantle flow around the Eurasian slab acting as a keel relative to the surrounding mantle. Such flow was already investigated by analog model of subduction rollback (e.g., Buttles and Olson, 1998; Funiciello et al., 2006) as well as by numerical modelling (e.g., Piromallo et al., 2006). As SKS waves sample the lithosphere at rather small incidence angles (around $10^{\circ}$, as seen on Fig. S2), only stations located in the most internal domains of the belt could record seismic rays that crossed the steeply dipping lithospheric Eurasian slab beneath the Apulian plate. Interestingly, these internal stations are characterized by the smallest delay times, ranging between 0.8 and $1.2 \mathrm{~s}$ on average (Fig. 6) that can be explained using the anisotropic signature of a steeply dipping slab if the lineation in the downgoing slab is also steeply dipping. An incident SKS wave will therefore propagate close to the lineation, i.e., along weakly anisotropic directions (Mainprice et al., 2000). As a consequence, small splitting delays observed in the most internal domains of the belt can be explained by the nearly vertical slab. On the contrary, beneath the external parts of the belt, i.e., at distance of 50 to $150 \mathrm{~km}$ from the internal zones, we observe the largest $\delta \mathrm{t}$ (ranging between 1.4 and $1.8 \mathrm{~s}$, with a mean value around $1.5 \mathrm{~s}$ ) that cannot be explained by crustal anisotropy alone nor by lithospheric Alpine strain that is likely not widespread enough but restricted to upper crustal and to discrete strain zones. This suggests instead that an important part of the anisotropy observed by SKS splitting probably lies in the sublithospheric mantle as schematically suggested by Fig. 6: to explain $1.5 \mathrm{~s}$ delay time, and considering anisotropy magnitude between 3 to $5 \%$ (typical values observed in real mantle rocks (Ben Ismail and Mainprice, 1998; Mainprice et al., 2000)), one requires indeed anisotropic paths between 225 and $135 \mathrm{~km}$ long, respectively, i.e., much larger than the actual lithospheric thickness of the Eurasian plate in this area, evaluated by body and surface waves to be in the range 80 to $100 \mathrm{~km}$ (e.g., Lippitsch et al., 2003; Pedersen et al., 2003).

To explain both the amplitude and the trend of the anisotropy deduced from vertically travelling SKS waves, we therefore propose that the orogen-parallel anisotropy pattern beneath the external domains of the Alpine belt is generated by a pervasive asthenospheric fabric controlled by the shape of the subducting European lithosphere.

\subsection{Age and origin of the observed anisotropy}

If one accepts that part of the observed anisotropy may reflect an asthenospheric flow around the Alpine subduction, an important question concerns the age of that deformation and therefore, the active or past nature of the involved tectonic processes. The observed anisotropy pattern may indeed represent an active flow around the moving Alpine roots or may be simply preserved in the upper mantle since the last important tectonic and/or thermal episode. Although seismic anisotropy alone cannot distinguish between the two possibilities, some arguments may be discussed in that light.

Upper mantle seismic anisotropy beneath SE France was already interpreted as asthenospheric flow induced by the early stage of the Neogene Tyrrhenian slab rollback (Barruol and Granet, 2002; Barruol et al., 2004) that could have been made easier by the presence of hot mantle material rising beneath the Massif Central and feeding the Neogene to Quaternary volcanic activity in the Massif Central (e.g., Dautria et al., 2010). If this interpretation is still valid and would favour the idea of mantle strained at asthenospheric depth and preserved since Neogene, an alternative (and perhaps complementary) interpretation is to consider that the observed anisotropy pattern could correspond to asthenospheric material flowing around the Alpine lithospheric keel formed by the Eurasian lithospheric slab dipping in the mantle (Fig. 7a). Such flow may be induced by either the Eurasian plate motion and/or by some more regional active mantle flow within the upper mantle. The Eurasian plate motion that may drag the slab is unfortunately poorly defined since this plate is one of the slowest on Earth. In a no-net rotation frame (e.g., Kreemer et al., 2003), the Eurasian plate motion is characterized by a vector trending toward $\mathrm{N} 050^{\circ} \mathrm{E}$ and by slow velocities (20 to $25 \mathrm{~mm} / \mathrm{yr}$ ). In the hotspot reference frame, the Eurasian plate moves at a much slower velocity (10 to $20 \mathrm{~mm} / \mathrm{yr}$, for HS2- and HS3-Nuvel1A, respectively (Gripp and Gordon, 1990, 2002)) and toward azimuth close to $\mathrm{N} 240^{\circ} \mathrm{E}$. Our observed anisotropy $\phi$ pattern fits closely the northern, western, and southern sides of the arc-shaped lithospheric 


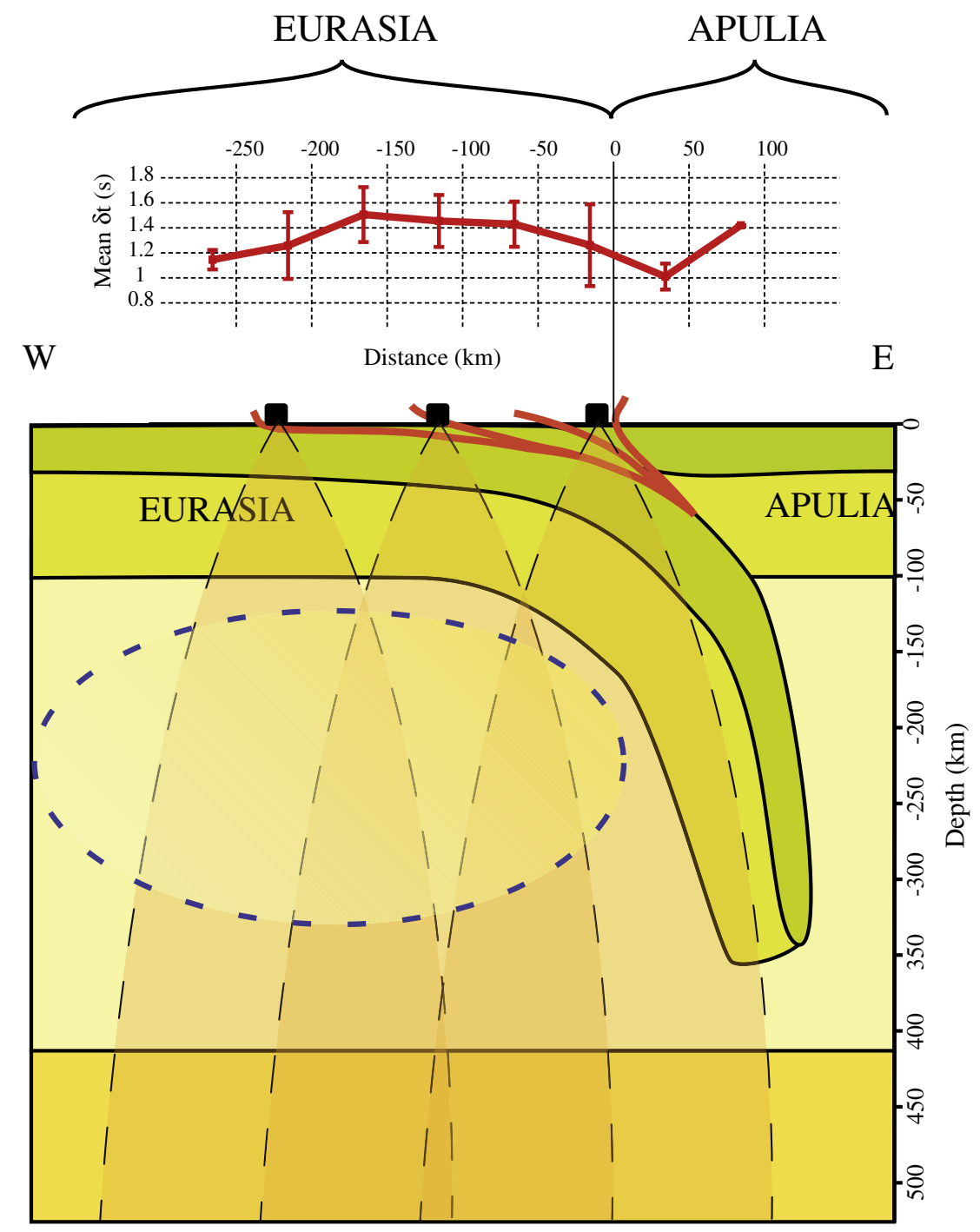

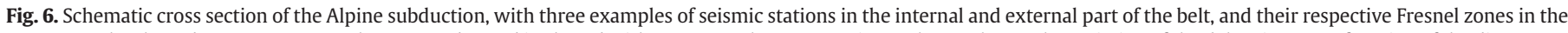

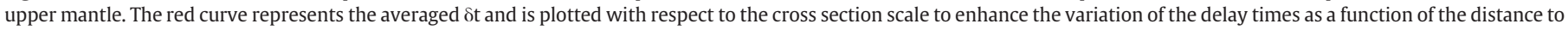
the boundary between Eurasia and Apulia. The dotted ellipse schematically represents the zone where higher anisotropy observed is supposed to be located.

slab in the upper mantle. This pattern is poorly compatible with a NEtrending plate motion that should align mantle lineations and fast split directions along NE-SW directions beneath the fore-arc side of the subduction, which is not observed. The $\phi$ pattern described in this study is more consistent with the hotspot-referenced plate motions, i.e., with a westward or south-westward plate motion vector that should explain a passive mantle flow around the slab. This plate motion direction is also compatible with the anisotropy pattern observed by Walker et al. (2005) around the Eifel hotspot in Germany and interpreted as an interaction between a mantle upwelling and the Eurasian plate motion toward WSW direction. Even though the trend of $\phi$ is compatible with a model of plate drag toward the SW and a passive asthenosphere (hypothesis illustrated Fig. 7a), the strength and broadness of the observed $\delta$ t illustrated in Figs. 5 and 6 suggest a rather strong flow, which may be not consistent with the slow $(<20 \mathrm{~mm} / \mathrm{yr})$ Eurasian plate motion. An alternative - and likely non exclusive - explanation to a present-day passive asthenospheric flow around the slab is therefore to infer a regional active flow that may have various origins: i) the subducting European lithosphere appears discontinuous beneath the Western Alps (Lippitsch et al., 2003) in the seismic tomographies and could suggest the detachment of the European slab at approximately $110-150 \mathrm{~km}$ depth, that could be presently freely falling in the upper mantle, inducing flow around it (schematized Fig. 7b). ii) The westward retreat of the Eurasian slab could be forced by the toroidal flow expelled by the Apennine slab rollback (hypothesis schematized Fig. 7c) (Funiciello et al., 2006; Piromallo et al., 2006; Vignaroli et al., 2008). The contemporaneous bending of the Western Alps and the rotation of the Corsica-Sardinia lithospheric blocks deduced from paleomagnetic data (e.g., Maffione et al., 2008) strongly suggest close relationships between the built up of the Alps and Apennines, in particular through the two opposite and contemporary rollbacks. As suggested by Jolivet et al. (2009), the Neogene eastward retreat of the Apennine slab may have simultaneously induced a suction effect of the asthenospheric mantle lying beneath the fore-arc side of the Alpine subduction and a forced westward return flow on the back-arc side of the Alpine subduction, i.e., beneath the Po plain. This hypothesis could be tested by investigating the anisotropy pattern above the backarc side of the Alpine subduction, across the Po plain in Northern Italy, where one could expect subduction-perpendicular trending $\phi$, i.e., EW-trending fast directions.

Interestingly, the strong variation of SKS splitting parameters at PCP station in the Voltri massif in the Ligurian Alps (Fig. 3 and Supplementary Fig. S3) is correlated with event backazimuth and can 

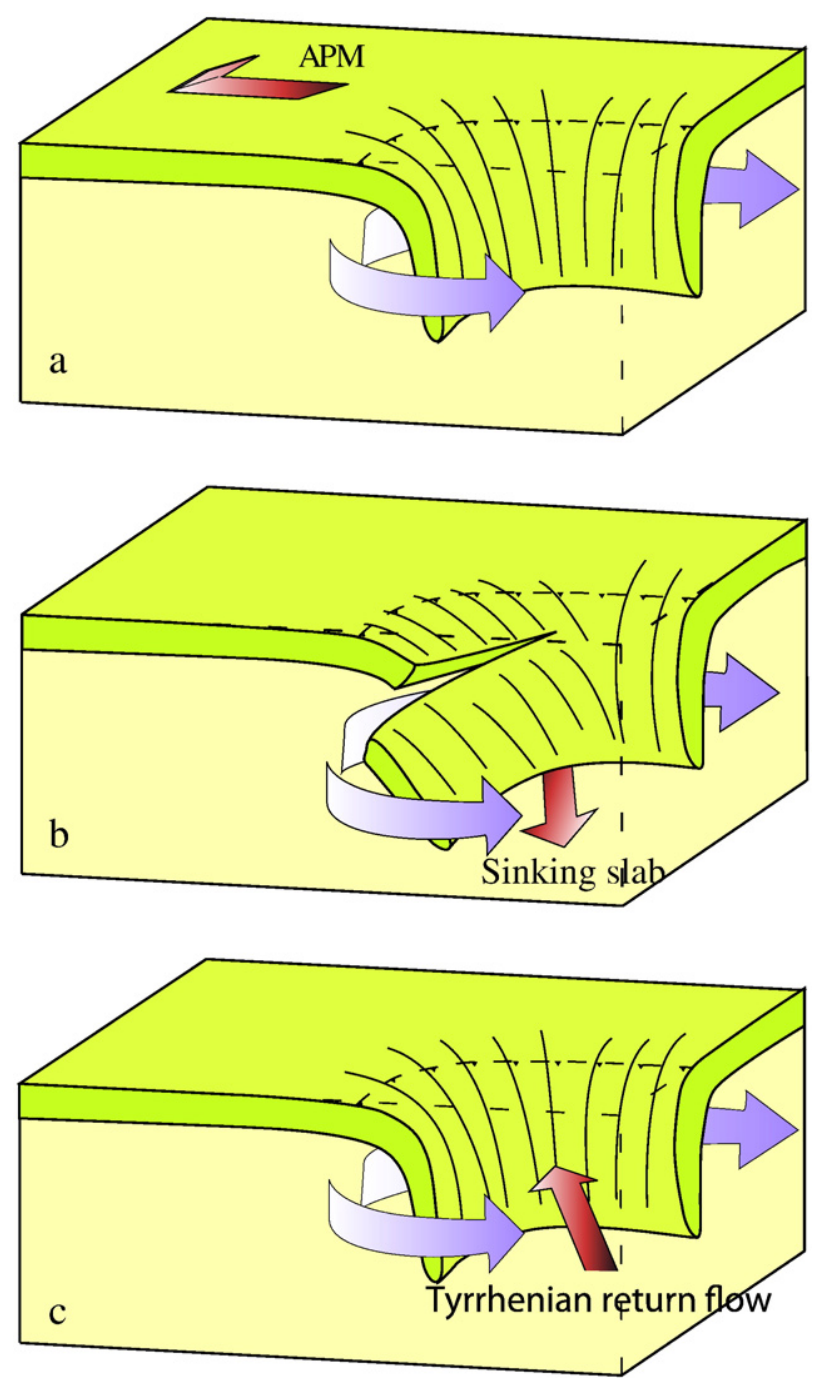

Fig. 7. Schematic bloc diagrams with roughly EW and NS cross sections presenting hypothetical processes that could explain the belt-parallel mantle flow beneath the Western Alps. a) The toroidal flow may be induced by the keel effect of the European slab moving in the direction of the absolute plate motion (APM) of the Eurasian plate. b) The belt-parallel anisotropy may result from the detachment of the sinking European slab, inducing a mantle flow around it. c) Anisotropic pattern may result from the interaction between the rollbacks of the European and Apennines slabs.

represent the various impacts from the above hypotheses. It lies in a particularly interesting transitional domain between the Alps and the Apennines that has been described as having accommodated strong $\approx \mathrm{EW}$ extension due to the opposite migrations of the eastward dipping Alpine slab and westward-dipping and eastward-retreating Tyrrhenian slabs during Cenozoic times (Jolivet et al., 2009; Vignaroli et al., 2008). The strong variation of splitting measurements (Fig. 3 and Supplementary Figs. S2 and S5) observed at PCP is correlated with event backazimuth: i) events arriving at PCP from the SW provide $\phi$ ranging between $\mathrm{EW}$ to $\mathrm{N} 110^{\circ} \mathrm{E}$, i.e., with a signature very similar to stations further west in SE France (Barruol et al., 2004) that could represent the asthenospheric anisotropy beneath the Eurasian slab in SE France, ii) events arriving at PCP from the east show $\mathrm{N} 110^{\circ} \mathrm{E}$ trending $\phi$, similar to what is observed further east in the Apennines (Plomerova et al., 2006; Salimbeni et al., 2008) and that could correspond to the anisotropy beneath the Apennine slab, and iii) events arriving at $\mathrm{PCP}$ in the $\mathrm{NE}$ quadrant show $\approx \mathrm{N} 060^{\circ} \mathrm{E}$ trending $\phi$, that could represent the present-day toroidal flow escaping from behind the retreating Apennine slab or a past, Neogene, vertical strike slip deformation induced by the relative motion between the two subductions of opposite polarities.

\section{Conclusions}

Systematic SKS splitting measurements at the Western Alps broadband stations provide a coherent picture of upper mantle flow beneath this halted orogen. The anisotropy pattern is characterized by a dominant belt-parallel fast split directions and by strong delay times beneath the external units of the belt. We propose that this pattern is dominated by sublithospheric mantle flow induced by present or recent relative motion between the subducting Eurasian lithosphere and the surrounding asthenospheric mantle. The issue relative to the active and/or past nature of the asthenospheric flow cannot be solved by anisotropy alone since both should generate similar signature. The clear SKS anisotropy pattern mimicking the shape of the Alpine mountain belt, the build-up of which has ended, suggests that mantle strain may be preserved as long as subsequent thermal or tectonic event does not reactivate it. In the larger frame of the Mediterranean tectonics, this work proposes a new arc-shaped mantle flow beneath a continental collision, controlled by the interaction between retreating slabs and the sublithospheric mantle, as what has been observed beneath Calabria (Baccheschi et al., 2007; Civello and Margheriti, 2004), the Apennines (Margheriti et al., 1996, 2003; Plomerova et al., 2006; Salimbeni et al., 2007), Gibraltar arc (Buontempo et al., 2008; Diaz et al., 2010), and the Aegean (Hatzfeld et al., 2001; Schmid et al., 2004). This confirms that large-scale tectonics induced by slab displacements within the upper mantle is a dominant process that shaped the whole Mediterranean area.

Supplementary materials related to this article can be found online at doi:10.1016/j.epsl.2010.12.040.

\section{Acknowledgements}

The facilities of the Swiss Digital Seismic Network and of the Regional Seismic network of Northern Italy were used for access to the waveforms and metadata required in this study for the Swiss and Italian stations. French broadband seismic data were provided by the GeoAzur, ReNaSS, GEOSCOPE and LGIT data centers. Thanks for the online availability and the high quality of all of these data. This paper benefited from discussions with Renaud Caby and from constructive comments from C. Faccenna and an anonymous reviewer. SplitLab software and the SKS splitting database are freely available at http:// www.gm.univ-montp2.fr/splitting/.

\section{References}

Alsina, D., Snieder, R., 1995. Small-scale sublithospheric continental mantle deformation: constraints from SKS splitting informations. Geophys. J. Int. 123, 431-448.

Baccheschi, P., Margheriti, L., Steckler, M.S., 2007. Seismic anisotropy reveals focused mantle flow around the Calabrian slab (Southern Italy). Geophys. Res. Lett. 34 (5), L05302, doi:10.1029/2006gl028899.

Barruol, G., Granet, M., 2002. A Tertiary asthenospheric flow beneath the southern French Massif Central indicated by upper mantle seismic anisotropy and related to the west Mediterranean extension. Earth Planet. Sci. Lett. 202 (1), 31-47, doi:10.1016/S0012-821X(02)00752-5.

Barruol, G., Hoffmann, R., 1999. Seismic anisotropy beneath the Geoscope stations from SKS splitting. J. Geophys. Res. 104, 10757-10774.

Barruol, G., Silver, P.G., Vauchez, A., 1997. Seismic anisotropy in the eastern US: deep structure of a complex continental plate. J. Geophys. Res. 102, 8329-8348.

Barruol, G., Deschamps, A., Coutant, O., 2004. Mapping Upper mantle anisotropy beneath SE France by SKS splitting indicates a Neogene asthenospheric flow induced by the Apenninic slab rollback and deflected by the deep Alpine roots. Tectonophysics 394 (1-2), 125-138, doi:10.1016/j.tecto.2004.08.002.

Ben Ismail, W., Mainprice, D., 1998. An olivine fabric database: an overview of upper mantle fabrics and seismic anisotropy. Tectonophysics 296, 145-157.

Buontempo, L., Bokelmann, G.H.R., Barruol, G., Morales, J., 2008. Seismic anisotropy beneath Southern Iberia from SKS splitting. Earth Planet. Sci. Lett. 273 (3-4), 237-250, doi:10.1016/j.epsl.2008.06.024.

Buttles, J., Olson, P., 1998. A laboratory model of subduction zone anisotropy. Earth Planet. Sci. Lett. 164, 245-262.

Civello, S., Margheriti, L., 2004. Toroidal mantle flow around the Calabrian slab (Italy) from SKS splitting. Geophys. Res. Lett. 31, L10601, doi:10.1029/2004GL019607.

Dautria, J.-M., Liotard, J.-M., Bosch, D., Alard, O., 2010. 160 Ma of sporadic basaltic activity on the Languedoc volcanic line (Southern France): a peculiar case of 
lithosphere-asthenosphere interplay. Lithos 120 (1-2), 202-222, doi:10.1016/j. lithos.2010.04.009.

Debayle, E., Kennett, B.L.N., Priestley, K., 2005. Global azimuthal seismic anisotropy and the unique plate-motion deformation of Australia. Nature 433, 509-512, doi:10.1038/nature03247.

Diaz, J., Gallart, J., Villasenor, A., Mancilla, F., Pazos, A., Cordoba, D., Pulgar, J., Ibarra, P., Harnafi, M., 2010. Mantle dynamics beneath the Gibraltar Arc (western Mediterranean) from shear-wave splitting measurements on a dense seismic array. Geophys. Res. Lett. 37 (L18304), doi:10.1029/2010GL044201.

Faccenna, C., Becker, T.W., Lucente, F.P., Jolivet, L., Rossetti, F., 2001. History of subduction and Back-arc extension in the Central Mediterranean. Geophys. J. Int. $145,809-820$.

Faccenna, C., Piromallo, C., Crespo-Blanc, A., Jolivet, L., Rossetti, F., 2004. Lateral slab deformation and the origin of the western Mediterranean arcs. Tectonics 23 (TC1012), doi:10.1029/2002TC001488.

Ferrandini, J., Gattacceca, J., Ferrandini, M., Deino, A., Janin, M.C., 2003. Chronostratigraphy and paleomagnetism of Oligo-Miocene deposits of Corsica (France): geodynamic implications for the liguro-provencal basin spreading. Bull. Soc. Geol. Fr. 174 (4), 357-371.

Fry, B., Deschamps, F., Kissling, E., Stehly, L., Giardini, D., 2006. Layered azimuthal anisotropy of Rayleigh wave phase velocities in the European Alpine lithosphere inferred from ambient noise. Earth Planet. Sci. Lett. 297, 95-102, doi:10.1016/j.epsl.2010.06.008.

Funiciello, F., Moroni, M., Piromallo, C., Faccenna, C., Cenedese, A., Bui, H.A., 2006. Mapping mantle flow during retreating subduction: laboratory models analyzed by feature tracking. J. Geophys. Res. 111, B03402, doi:10.1029/2005jb003792.

Gattacceca, J., Deino, A., Rizzo, R., Jones, D.S., Henry, B., Beaudoin, B., Vadeboin, F., 2007. Miocene rotation of Sardinia: new paleomagnetic and geochronological constraints and geodynamic implications. Earth Planet. Sci. Lett. 258 (3-4), 359-377, doi:10.1016/j.epsl.2007.02.003.

Gripp, A.E., Gordon, R.G., 1990. Current plate velocities relative to the hotspots incorporating the Nuvel-1 global plate motion model. Geophys. Res. Lett. 17, 1109-1112.

Gripp, A.E., Gordon, R.B., 2002. Young tracks of hotspots and current plate velocities. Geophys. J. Int. 150, 321-361.

Hatzfeld, D., karagianni, E., Kassaras, I., Kiratzi, A., Louvari, E., lyon-Caen, H., Makropoulos, K., Papadimitriou, P., Bock, G., Priestley, K., 2001. Shear wave anisotropy in the upper mantle beneath the Aegean related to internal deformation. J. Geophys. Res. 106 (12), 30737-30753.

Ivan, M., Popa, M., Ghica, D., 2008. SKS splitting observed at romanian broad-band seismic network. Tectonophysics 462, 89-98, doi:10.1016/j.tecto.2007.12.015.

Jolivet, L., Faccenna, C., Piromallo, C., 2009. From mantle to crust: stretching the Mediterranean. Earth Planet. Sci. Lett. 285, 198-209, doi:10.1016/j.epsl.2009.06.017.

Kreemer, C., Holt, W.E., Haines, A.J., 2003. An integrated global model of present-day plate motions and plate boundary deformation. Geophys. J. Int. 154 (1), 8-34

Kummerow, J., Kind, R., 2006. Shear wave splitting in the Eastern Alps observed at the TRANSALP network. Tectonophysics 414 (1-4), 117-125.

Lippitsch, R., Kissling, E., Ansorge, J., 2003. Upper mantle structure beneath the Alpine orogen from high resolution teleseismic tomography. J. Geophys. Res. 108 (B8), 2376, doi:10.1029/2002JB002016.

Lucente, F.P., Margheriti, L., Piromallo, C., Barruol, G., 2006. Seismic anisotropy reveals the long route of the slab through the western-central Mediterranean mantle. Earth Planet. Sci. Lett. 241 (3-4), 517-529, doi:10.1016/j.epsl.2005.10.041.

Maffione, M., Speranza, F., Faccenna, C., Cascella, A., Vignaroli, G., Sagnotti, L., 2008. A synchronous Alpine and Corsica-Sardinia rotation. J. Geophys. Res. 113 (B03104), doi:10.1029/2007jb005214.

Mainprice, D., Barruol, G., Ben Ismail, W., 2000. The seismic anisotropy of the Earth's mantle: from single crystal to polycrystal. In: Karato, S.I., Forte, A., Liebermann, R.C., Masters, G., Stixrude, L. (Eds.), Earth's Deep Interior: Mineral Physics and Tomography from the Atomic to the Global Scale. Geophysical Monograph. AGU, Washington, D.C., pp. 237-264.

Margheriti, L., Nostro, C., Cocco, M., Amato, A., 1996. Seismic anisotropy beneath the northern Apennines (Italy) and its tectonic implications. Geophys. Res. Lett. 23, 2721-2724.

Margheriti, L., Lucente, F.P., Pondrelli, S., 2003. SKS splitting measurements in the Apenninic-Tyrrhenian domain (Italy) and their relation with lithospheric subduction and mantle convection. J. Geophys. Res. 108 (B4), 2218, doi:10.1029/ 2002JB001793.

Masson, F., Verdun, J., Bayer, R., Debeglia, N., 1999. Une nouvelle carte gravimétrique des Alpes occidentales et ses conséquences structurales et tectoniques. CR Acad. Sci. Paris 329, 865-871.

Matte, P., 1986. Tectonics and plate tectonics model for the Variscan belt of Europe. Tectonophysics 126, 329-374.

Nicolas, A., Christensen, N.I., 1987. Formation of anisotropy in upper mantle peridotites -a review. In: Fuchs, K., Froidevaux, C. (Eds.), Composition, Structure and
Dynamics of the Lithosphere-Asthenosphere System. Geodyn. Ser. AGU, Washington, D. C, pp. 111-123.

Pedersen, H.A., Coutant, O., Deschamps, A., Soulage, M., Cotte, N., 2003. Measuring surface wave phase velocities beneath small broad-band arrays: tests of an improved algorithm and application to the French Alps. Geophys. J. Int. 154 (3), 903-912.

Piromallo, C., Faccenna, C., 2004. How deep can we find the traces of Alpine subduction? Geophys. Res. Lett. 31, L06605, doi:10.1029/2003GL019288.

Piromallo, C., Morelli, C., 2003. P wave tomography of the mantle under the AlpineMediterranean area. J. Geophys. Res. 108 (B2), 2065, doi:10.1029/2002JB001757.

Piromallo, C., Becker, T.W., Funiciello, F., Faccenna, C., 2006. Three-dimensional instantaneous mantle flow induced by subduction. Geophys. Res. Lett. 33, L08304, doi:10.1029/2005gl025390.

Plomerova, J., Margheriti, L., Park, J., Babuska, V., Pondrelli, S., Vecsey, L., Piccinini, D., Levin, V., Baccheschi, P., Salimbeni, S., 2006. Seismic anisotropy beneath the Northern Apennines (Italy): mantle flow or lithosphere fabric? Earth Planet. Sci. Lett. 247 (1-2), 157-170, doi:10.1016/j.epsl.2006.04.023.

Salimbeni, S., Pondrelli, S., Margheriti, L., Levin, V., Park, J., Plomerova, J., Babuska, V., 2007. Abrupt change in mantle fabric across northern Apennines detected using seismic anisotropy. Geophys. Res. Lett. 34 (7), L07308.

Salimbeni, S., Pondrelli, S., Margheriti, L., Park, J., Levin, V., 2008. SKS splitting measurements beneath Northern Apennines region: a case of oblique trenchretreat. Tectonophysics 462 (1-4), 68-82, doi:10.1016/j.tecto.2007.11.075.

Savage, M.K., 1999. Seismic anisotropy and mantle deformation: what have we learned from shear wave splitting? Rev. Geophys. 37, 65-106.

Schellart, W.P., 2008. Kinematics and flow patterns in deep mantle and upper mantle subduction models: influence of the mantle depth and slab to mantle viscosity ratio. Geochem. Geophys. Geosyst. 9 (Q03014), doi:10.1029/2007gc001656.

Schmid, C., Van der Lee, S.F., Giardini, D., 2004. Delay times and shear wave splitting in the Mediterranean region. Geophys. J. Int. 159, 275-290.

Silver, P.G., 1996. Seismic anisotropy beneath the continents: probing the depths of geology. Ann. Rev. Earth Planet. Sci. 24, 385-432.

Silver, P.G., Chan, W.W., 1991. Shear wave splitting and subcontinental mantle deformation. J. Geophys. Res. 96, 16429-16454.

Silver, P.G., Mainprice, D., Ben Ismail, W., Tommasi, A., Barruol, G., 1999. Mantle structural geology from seismic anisotropy. In: Fei, Y., Bertka, C., Mysen, B. (Eds.) Mantle Petrology: Field Observations and High Pressure Experimentation: A Tribute to Francis R. (Joe) Boyd. Stony Brooks, pp. 79-103.

Spakman, W., Van der lee, S., Van der hilst, R., 1993. Travel-time tomography of the European Mediterranean mantle down to 1400 km. Phys. Earth Planet. Int. 79 (12), 3-74.

Stehly, L., Fry, B., Campillo, M., Shapiro, N.M., Guilbert, J., Boschi, L., Giardini, D., 2009 Tomography of the Alpine region from observations of seismic ambient noise. Geophys. J. Int. 178 (1), 338-350, doi:10.1111/j.1365-246X.2009.04132.x.

Tesauro, M., Kaban, M.K., Cloetingh, S., 2008. EuCRUST-07: a new reference model for the European crust. Geophys. Res. Lett. 35, L05313, doi:10.1029/2007GL032244.

Thouvenot, F., Paul, A., Frechet, J., Bethoux, N., Jenatton, L., Guiguet, R., 2007. Are there really superposed Mohos in the southwestern Alps? New seismic data from fan-profiling reflections. Geophys. J. Int. 170 (3), 1180-1194, doi:10.1111/j.1365-246X.2007.03463.X.

Vauchez, A. Bufalo, M. 1988. Charriage crustal, anatexie et décrochement ductile dans les Maures orientales (Var, France) au cours de l'orogène Varisque. Geol. Rundsch. 77, 45-62.

Vignaroli, G., Faccenna, C., Jolivet, L., Piromallo, C., Rossetti, F., 2008. Subduction polarity reversal at the junction between the Western Alps and the Northern Apennines, Italy. Tectonophysics 450 (1-4), 34-50, doi:10.1016/j.tecto.2007.12.012.

Waldhauser, F., Kissling, E., Ansorge, J., Mueller, S., 1998. Three dimensionnal interface modelling with two-dimensional seismic data: the Alpine crust-mantle boundary. Geophys. J. Int. 135, 264-278.

Walker, K.T., Bokelmann, G.H.R., Klemperer, S.L., Bock, G., 2005. Shear-wave splitting around the Eifel hotspot: evidence for a mantle upwelling. Geophys. J. Int. 163, doi:10.1111/j.1365-246X.2005.02636.x.

Wortel, M.J.R., Spakman, W., 2000. Subduction and Slab Detachment in the Mediterranean-Carpathian Region. Science 290 (5498), 1910-1917.

Wuestefeld, A., Al-Harrasi, O., Verdon, J.P., Wookey, J., Kendall, J.M., 2010. A strategy for automated analysis of passive microseismic data to image seismic anisotropy and fracture characteristics. Geophys. Prospect. 58 (5), 755-773, doi:10.1111/j.13652478.2010.00891.x.

Wüstefeld, A., Bokelmann, G.H.R., Zaroli, C., Barruol, G., 2008. SplitLab: a shear-wave splitting environment in Matlab. Comput. Geosci. 34, 515-528, doi:10.1016/j. cageo.2007.08.002.

Wüstefeld, A., Bokelmann, G.H.R., Barruol, G., Montagner, J.P., 2009. Identifying global seismic anisotropy patterns by correlating shear-wave splitting and surface-wave data. Phys. Earth Planet. Int. 176, 198-212, doi:10.1016/j.pepi.2009.05.006. 